\title{
Kontribusi Pelayanan Terhadap Kepuasan Nasabah Bank Muamalat
}

\author{
Widia Astuti $^{\mathrm{a}, 1}$, Norhayatun ${ }^{\mathrm{a}, 2}$, M. Qahfi ${ }^{\mathrm{a}, 3}$ \\ ${ }^{a}$ STKIP Muhammadiyah Sampit, Kalimantan Tengah, Indonesia \\ ${ }^{1}$ widiaastuti2507@gmail.com \\ 'norhayatun68@gmail.com \\ Imuhamat_qahfi@yahoo.com
}

\section{ABSTRACT}

Article history:

Received : 2018-03-16

Revised : 2018-06-29

Accepted : 2018-06-30

Keywords:

Effect

Contribution

Service

Customer satisfaction

This study is conducted to investigate the service to customers' satisfaction at Bank Muamalat Branch of Sampit. To measure variables: 1) Convenience, 2) customer relationship with employees, 3 ) technical compensation of officers, and 4) costs. To measure the quality variable of place of five aspects; 1) physical form (tangibles), 2) reliability, 3) responsiveness, 4) assurance, and 5) empathy. The proposed hypothesis is that the service effect on customers' satisfaction. The research populations were 7000 customers. Sampling technique was done using accidental sampling technique with total sample of 32 customers. Data collection techniques used a questionnaire fulfiling the requirements of validity and reliability. Data analysis teachniqe used simple linear regression analysis technique fulfilling requirements: normality test, linearity and autocorrelation test. From the research data description, they were the variables belonged to high category $3 \%$, medium category $84 \%$, and low category $13 \%$. Meanwhile, the satisfaction belonged to high category was $22 \%$, medium category was $53 \%$, and low category was $25 \%$. The problems were related to service and satisfaction for the medium category. This study revealed that there was an effect of service to customer satisfaction at Bank Muamalat Branch of Sampit about $14.3 \%$.

Copyright $@ 2018$ IAIN Palangka Raya. All rights reserved.

\section{Pendahuluan}

Bank dapat dipahami sebagai lembaga keuangan yang memberikan konstribusi dalam perkembangan dan pertumbuhan suatu bangsa, tak terkecuali Indonesia. Menurut Undang-Undang No. 10 tahun 1998, bank adalah badan usaha yang menghimpun dana dari masyarakat dalam bentuk simpanan dan menyalurkannya kepada masyarakat dalam bentuk kredit atau bentuk-bentuk lainnya dalam rangka meningkatkan taraf hidup rakyat banyak.

Keberadaan bank maupun lembaga keuangan yang lain semakin tahun terus bertambah, tentunya persaingan dalam dunia bisnis semakin tajam. Persaingan ini menuntut pelaku untuk mampu memaksimalkan kinerja perusahaannya agar dapat bersaing dipasar. Untuk memenangkan persaingan, perusahaan harus mampu memberikan kepuasan kepada pelanggannya, misalnya dengan memberikan produk yang kualitasnya baik. Produk dengan kualitas jelek dan pengiriman produk yang lambat bisa membuat pelanggan tidak puas, walaupun dengan tingkat kepuasan yang berbeda. Jika nilai kepuasan dari pelanggan adalah kenyamanan maka kepuasan akan datang apabila pelayanan yang diperoleh benar-benar dapat membuat pelanggan tersebut merasa nyaman. Kalau penilaian dari pelanggan adalah harga yang murah, maka pelanggan akan puas kepada produsen yang memberikan harga yang paling kompetitif.

Menurut Kotler, kepuasan pelanggan adalah perasaan senang atau kecewa seseorang yang muncul setelah membandingkan antara persepsi/kesannya terhadap kinerja (hasil) suatu produk dan harapan-harapannya.(1) Kepuasan pelanggan merupakan suatu hal yang sangat berharga demi mempertahankan keberadaan pelanggan 
tersebut agar suatu bisnis atau usaha tetap berjalan.

Disisi lain, setiap perusahaan tentunya mengandalkan produk-produk yang mereka tawarkan kepada pelanggan untuk menciptakan kepuasan pelanggan. Lalu siapakah yang bakal bertahan di era persaingan bisnis yang seperti ini?. Tidak ada cara lain selain harus mempunyai strategi jitu dan meningkatkan kualitas kinerja dan pelayanan secara terus-menerus, serta membangun paradigma baru perusahaan terhadap pelanggan. Paradigma baru tersebut adalah perusahaan harus memusatkan perhatian sepenuhnya kepada pelanggan. Kalau dulu pelanggan mencari perusahaan, maka sekarang perusahaanlah yang harus aktif mencari pelanggan.

Perusahaan harus pandai mencari cara bagaimana dipercaya dan disukai pelanggan. Karena jika pelanggan merasa percaya dan puas kepada perusahaan, pelanggan tersebut akan menjatuhkan pilihan selanjutnya pada perusahaan. Kepuasan pelanggan sebagai hasil penilaian pelanggan terhadap apa yang diharapkannya dengan membeli suatu produk/jasa. Kemudian harapan tersebut dibandingkan dengan kinerja yang diterimanya dengan mengkonsumsi produk/jasa tersebut. Apakah keinginan yang diterimanya lebih besar (minimal sama) daripada harapannya, maka pelanggan puas. Sebaliknya, jika kinerja yang diberikan dari pemakaian produk/jasa tersebut lebih kecil daripada apa yang diharapkannya maka pelanggan tidak puas.

Kaitannya dengan penjelasan diatas, berhubungan dengan kondisi riil dilapangan yang penulis temukan di Bank Muamalat Cabang Pembantu Sampit, penulis mendapatkan informasi adanya keluhankeluhan dari nasabah yang artinya kepuasan nasabah belum maksimal. Nasabah mengeluhkan masalah transaksi yang gagal melalui fasilitas Automatic Teller Machine (ATM) karena gangguan jaringan dari penyedia jasa jaringan ATM baik itu ATM Bersama atau Prima, dan setelah melakukan wawancara dengan nasabah, keluhan dari nasabah lainnya adalah pelayanan yang menunggu agak lama ketika nasabah menginginkan pelayanan dari customer service karena petugas customer service di
Bank Muamalat Cabang Pembantu Sampit hanya 1 orang, padahal seharusnya pelayanan dalam dunia bisnis ini lebih diutamakan, karena pelanggan tidak hanya menilai dari hasil jasa, tetapi juga dari proses penyampaian jasa tersebut.

Tujuan dari pelayanan yang baik adalah mencegah pembelotan dan membangun kesetiaan pelanggan atau customer loyality. Pembelotan pelanggan atau berpalingnya pelanggan disebabkan karena kesalahan pemberian pelayanan maupun sistem yang digunakan oleh perusahaan dalam melayani pelanggan. Pelanggan diibaratkan seorang raja yang harus dilayani, namun hal ini bukan berarti perusahaan jasa tidak mendapatkan keuntungan dari pelayanan yang diberikan kepada pelanggan, peningkatan pelayanan bertujuan agar para pelanggan merasa puas dan pada akhirnya pelanggan-pelanggan yang lain pun akan mengikuti sehingga menjadi pelanggan perusahaan yang dimilikinya. Jadi antara kedua belah pihak saling diuntungkan.

Untuk memberikan kepuasan tentu peningkatan pelayanan menjadi kunci dari kesuksesan perusahaan, berbagai cara untuk melayani pelanggan tentu harus dilakukan. Pelayanan yang berkualitas akan mampu memenuhi harapan pelanggan dan bahkan dipastikan pelanggan tersebut akan puas meskipun dengan tingkat kepuasan yang berbeda.

Berdasarkan uraian diatas, rumusan masalah yang diajukan dalam penelitian ini yaitu apakah ada pengaruh pelayanan terhadap kepuasan nasabah di Bank Muamalat Cabang Pembantu Sampit?, sehingga yang menjadi tujuan dalam penelitian ini yaitu untuk mengetahui pengaruh pelayanan terhadap kepuasan nasabah di Bank Muamalat Cabang Pembantu Sampit.

\section{Kajian Pustaka}

Menurut Undang-Undang RI Nomor 10 Tahun 1998 tanggal 10 November 1998 tentang Perbankan, yang dimaksud dengan bank adalah badan usaha yang menghimpun dana dari masyarakat dalam bentuk simpanan dan menyalurkannya kepada masyarakat dalam bentuk kredit dan atau bentuk-bentuk lainnya dalam rangka meningkatkan taraf hidup rakyat banyak.(8) 
Undang-Undang Perbankan Indonesia, Undang-Undang No.7 tahun 1992 tentang Perbankan, digantikan oleh Undang-Undang No.10 tahun 1998, membedakan bank berdasarkan kegiatan usahanya menjadi dua, yaitu bank yang melaksanakan kegiatan usaha secara konvensional dan bank yang melaksanakan kegiatan usaha berdasarkan prinsip syariah.(15)

\section{1) Bank Konvensional}

Menurut Undang-undang Nomor 10 Tahun 1998 Bank Konvensional adalah bank yang melaksanakan kegiatan usaha secara konvensional yang dalam kegiatannya memberikan jasa dalam lalu lintas pembayaran. Martono menjelaskan prinsip konvensional yang digunakan bank konvensional menggunakan dua metode, yaitu:

a) Menetapkan bunga sebagai harga, baik untuk produk simpanan seperti tabungan, deposito berjangka, maupun produk pinjaman (kredit) yang diberikan berdasarkan tingkat bunga tertentu.

b) Untuk jasa-jasa bank lainnya, pihak bank menggunakan atau menerapkan berbagai biaya dalam nominal atau persentase tertentu. Sistem penetapan biaya ini disebut fee based.

\section{2) Bank Syariah}

Menurut Sudarsono, Bank Syariah adalah lembaga keuangan yang usaha pokoknya memberikan kredit dan jasa-jasa lain dalam lalu lintas pembayaran, serta peredaran uang yang beroperasi dengan prinsip syariah.(15) Salah satu Bank yang menjalankan sistem Perbankan Syariah di Indonesia khususnya di kota Sampit adalah Bank Muamalat Cabang Pembantu Sampit. Seperti halnya bank yang lain, bank Muamalat juga memperhatikan kualitas pelayanan untuk menjaga kepuasan nasabah.

Menurut Kotler, kepuasan merupakan tingkat perasaan di mana seseorang menyatakan hasil perbandingan antara hasil kerja produk/jasa yang diterima dengan apa yang diharapkan.(1) Wilkie mendefinisikan kepuasan sebagai suatu tanggapan emosional pada evaluasi terhadap pengalaman konsumsi suatu produk atau jasa.(6) Menurut Engel kepuasan adalah penilaian kepuasan atau ketidakpuasan terhadap suatu produk atau jasa dari suatu perusahaan berdasarkan pada hasil yang dirasakan dengan harapan yang dimiliki oleh pelanggan.(5)

Dari pengertian diatas dapat disimpulkan bahwa kepuasan adalah perasaan senang pelanggan terhadap produk/jasa yang didapatkan karena sesuai dengan harapannya.

Ada tiga jenis kepuasan nasabah:(3)

a) Puas dengan produk/jasa bank yaitu karena kualitasnya tinggi serta jangkauannya yang luas.

b) Puas dengan cara menjualnya: Ramah, sopan dan akrab, murah senyum, menyenangkan, tanggap, cepat dan cermat.

c) Puas dengan harganya: Murah/mahal sesuai harapan, bersaing.

Kepuasan nasabah terkait dengan kualitas pelayanan internal dan kepuasan pelayanan internal karyawan tentu akan mendorong kepuasan karyawan. Kepuasan karyawan akan mendorong bangkitnya loyalitas karyawan pada perusahaan. Selanjutnya loyalitas karyawan akan berdampak pada produktivitas. Produktivitas karyawan akan menciptakan dan menentukan kepuasan nasabah. Akhirnya kepuasan nasabah ini akan menciptakan loyalitas nasabah.(3)

Kepuasan nasabah yang diberikan bank akan berimbas sangat luas bagi peningkatan keuntungan bank. Atau dengan kata lain, apabila nasabah puas dengan pembelian jasa bank, maka nasabah tersebut akan:

a) Loyal kepada bank, artinya kecil kemungkinan nasabah untuk pindah ke bank yang lain dan akan tetap setia menjadi nasabah bank yang bersangkutan.

b) Mengulang kembali pembelian produknya, artinya kepuasan terhadap pembelian jasa bank akan menyebabkan nasabah membeli kembali terhadap jasa yang ditawarkan secara berulang-ulang.

c) Membeli lagi produk bank dalam bank yang sama dalam hal ini nasabah akan memperluas pembelian jenis jasa yang ditawarkan sehingga pembelian nasabah jadi beragam dalam satu bank.

d) Memberikan promosi gratis dari mulut ke mulut.(9) Hal inilah yang menjadi keinginan bank karena pembicaraan tentang kualitas pelayanan bank ke nasabah lain akan menjadi bukti akan kualitas yang ditawarakan. 
Namun, nasabah pun seringkali merasa tidak puas atas pelayanan yang diberikan oleh perusahaan. Sebab-sebab timbulnya ketidakpuasan para nasabah:

a) Tidak sesuai antara manfaat atau hasil yang diharapkan dengan kenyataan atau apa yang didapat oleh nasabah.

b) Layanan selama proses menikmati jasa tidak memuaskan.

c) Perilaku personil atau karyawan perusahaan atau bank yang kurang memuaskan atau mengecewakan nasabah.

d) Suasana dan kondisi fisik lingkungan tidak menunjang, misalkan tata letak gedung yang tidak tertata rapi.

e) Biaya yang terlalu tinggi, misalkan biaya administrasi bulanan yang terlalu tinggi di atas bank lain atau tingkat bagi hasil yang terlalu membebankan nasabah.

f) Promosi iklan yang terlalu berlebihan, sehingga seringkali tidak sesuai dengan kenyataan.(3)

Menurut Sugiarto, keluhan nasabah dapat dikategorikan atau dikelompokkan menjadi empat,(3) yaitu:

a) Mechanica complaint (keluhan mekanikal)

Keluhan mekanikal adalah suatu keluhan yang disampaikan oleh nasabah sehubungan dengan tidak dapat berfungsinya peralatan atau produk yang dibeli atau disampaikan kepada pelanggan tersebut. Misalkan kartu ATM (Automatic teller machine) yang tidak dapat digunakan karena petugas customer service yang lupa untuk mengaktifasi kartu ATM tersebut. Atau mesin ATM yang tidak dapat dipergunakan, maka nasabah bisa saja mengajukan keluhan kepada perusahaan dikarenakan tidak berfungsinya peralatan atau produk yang terkait dengan nasabah.

Atau dapat pula nasabah yang salah memasukan nomor pin ATM sehingga kartu ATM-nya diblokir, sehingga nasabah harus menghubungi call center, maka petugas call center harus mampu membantu nasabah tersebut dengan prosedur yang berlaku.

b) Attitudinal complaint (keluhan akibat sikap karyawan perusahaan)

Keluhan nasabah muncul sebagai akibat sikap atau perilaku karyawan atau petugas pelayanan yang negatif pada saat melayani nasabah. Hal ini dapat dirasakan oleh nasabah melalui sikap tidak peduli dari petugas pelayanan terhadap nasabah. Misalkan ada nasabah yang hendak membuka rekening di suatu bank syariah, namun karena penampilan yang kurang meyakinkan nasabah tersebut tidak dipedulikan atau disepelekan. Atau adanya petugas customer service yang mempersulit nasabah ketika hendak bertransaksi.

b) Service related complaint (keluhan berkaitan dengan pelayanan)

Keluhan yang muncul terkait dengan pelayanan itu sendiri. Misalnya antrian teller yang terlalu lama dan panjang sehingga merugikan waktu nasabah. Atau kurang banyaknya kursi pada saat harus mengantri, sehingga banyak nasabah yang terpaksa berdiri menunggu antrian.

\section{c) Unusual complaint (keluhan yang aneh)}

Keluhan nasabah yang bagi petugas merupakan keanehan (tidak wajar atau tidak umum), karena tidak berhubungan dengan pelayanan atau produk bank. Nasabah yang mengeluh seperti ini sebenarnya secara psikologis adalah orang-orang yang hidupnya tidak bahagia atau kesepian. Misalkan ada seorang nasabah yang menghubungi call center suatu bank namun bukan untuk mengeluh atau mengkomunikasikan terkait pelayanan bank, akan tetapi ia menghubungi call center untuk bercerita tentang beban hidupnya atau 'curhat' tentang masalah percintaan yang dialami.

Menurut Sabarguna ada beberapa aspek kepuasan nasabah yaitu:

a) Kenyamanan, meliputi lokasi perusahaan, kebersihan, dan kenyamanan.

b) Hubungan pelanggan dengan karyawan, meliputi keramahan karyawan, informasi yang diberikan oleh karyawan, komunikatif, responsif, suportif, dan cekatan dalam melayani nasabah.

c) Kompetensi teknis petugas, meliputi keberanian bertindak dan pengalaman.

d) Biaya, meliputi mahalnya produk, terjangkau tidaknya oleh nasabah.(2)

Menurut Moenir, pelayanan merupakan rangkaian kegiatan untuk memenuhi 
kebutuhan pelanggan, atas jasa yang mereka dapatkan dari suatu perusahaan.(13) Menurut Sugiarto, pelayanan adalah suatu tindakan yang dilakukan untuk memenuhi kebutuhan orang lain (pelanggan, tamu, penumpang, klien, pembeli, pasien, dan lain-lain) yang tingkat pemuasannya hanya dapat dirasakan oleh orang yang melayani maupun yang dilayani.(13) Menurut Kotler, pelayanan (service) adalah aktivitas atau manfaat yang ditawarkan oleh suatu pihak kepada pihak lain yang pada dasarnya tidak berwujud dan tidak menghasilkan kepemilikan apapun.(11)

Dari pengertian-pengertian diatas dapat disimpulkan bahwa pelayanan merupakan proses pemberian bantuan atau manfaat yang diberikan perusahaan kepada pelanggannya.

Menurut Lovelock, terdiri atas lima aspek kualitas pelayanan, yang pertama bentuk fisik (Tangibles), yaitu kemampuan perusahaan (bank) dalam menunjukkan eksistensinya pada nasabah. Penampilan dan kemampuan sarana dan prasarana fisik perusahaan dan lingkungan sekitarnya. Bentuk bangunan, tata ruang, dan desain interior gedung merupakan bentuk fisik yang dapat meyakinkan nasabah. Aspek kedua kehandalan (Reliability), yaitu kemampuan perusahaan (bank) untuk memberikan pelayanan sesuai dengan yang dijanjikan. Aspek ketiga ketanggapan (Responsiveness), yaitu kemampuan bank untuk menolong nasabah dan ketersediaan untuk melayani nasabah dengan baik. Suatu kemampuan untuk membantu dan memberikan pelayanan yang cepat (responsiv) dan tepat kepada nasabah, dengan penyampaian informasi yang jelas. Aspek keempat, jaminan (Assurance), yaitu kemampuan pegawai bank untuk menumbuhkan rasa percaya para nasabah pada bank. Aspek terakhir, empaty (Empathy), yaitu memberikan perhatian yang tulus dan bersifat individual yang diberikan kepada para nasabah dengan berupaya memahami keinginan nasabah.(5)

Berdasarkan kajian teori yang ada, maka dikemukakan sebuah hipotesis penelitian. Hipotesis merupakan jawaban sementara berdasarkan kajian teori yang masih perlu dibuktikan kebenarannya. Menurut Sukardi, hipotesis secara definitif dapat berarti jawaban sementara yang kebenarannya masih diuji dengan data yang diperoleh dari lapangan.(14) Hipotesis dalam penelitian ini yaitu ada pengaruh pelayanan terhadap kepuasan nasabah di Bank Muamalat Cabang Pembantu Sampit.

\section{Metodologi Penelitian}

Penelitian ini dilaksanakan pada Juli 2016 - September 2016 di Bank Muamalat Cabang Pembantu Sampit yang terletak di Jl. AIS Nasution No.08 Kabupaten Kotawaringin Timur, Sampit, Kalimantan Tengah. Penelitian ini menggunakan metode penelitian kuantitatif. Menurut Stokes, penelitian kuantitatif adalah istilah yang digunakan untuk menggambarkan pendekatan-pendekatan yang dikembangkan dalam ilmu pengetahuan alam, dan kini digunakan secara luas dalam penelitian ilmu sosial.(12)

Menurut Hamdi, penelitian kuantitatif menekankan fenomena-fenomena objektif dan dikaji secara kuantitatif.(7) Maksimalisasi objektivitas desain penelitian ini dilakukan dengan menggunakan angka-angka, pengolahan statistik, struktur dan percobaan terkontrol.

Jenis pendekatan yang digunakan dalam penelitian ini adalah penelitian ex-postfacto. Menurut Sukardi, penelitian ex-postfacto merupakan penelitian dimana variabelvariabel bebas telah terjadi ketika peneliti mulai dengan pengamatan variabel terikat dalam suatu penelitian.(14)

Teknik analisis data yang digunakan dalam penelitian ini adalah analisis regresi linear sederhana. Analisis ini digunakan untuk menentukan hubungan antara dua gejala (variabel), yaitu digunakan untuk mengetahui pengaruh pelayanan terhadap kepuasan nasabah di Bank Muamalat Cabang Pembantu Sampit.

Menurut Arikunto, populasi adalah keseluruhan subjek penelitian.(4) Dalam penelitian ini yang menjadi populasi adalah seluruh nasabah Bank Muamalat Cabang Pembantu Sampit yang berjumlah 7.000 nasabah.

Menurut Arikunto, sampel adalah sebagian atau wakil populasi yang diteliti.(4) Sedangkan menurut Sukardi, sampel adalah sebagian dari jumlah populasi yang dipilih untuk sumber data.(14) Sampel penelitian 
berjumlah 32 responden yang mana pengambilan sampel menggunakan teknik accidental sampling. Menurut Sugiyono, accidental sampling adalah teknik penentuan sampel berdasarkan kebetulan, yaitu siapa saja yang secara kebetulan bertemu dengan peneliti dapat digunakan sebagai sampel, bila dipandang orang yang kebetulan ditemui itu cocok sebagai sumber data.(1)

Sedangkan menurut Sukardi, teknik accidental Sampling ini dikatakan secara kebetulan karena peneliti memang dengan sengaja memilih sampel kepada siapapun yang ditemuinya atau by accident pada tempat, waktu, dan cara yang telah ditentukan.(14)

Berdasarkan penjelasan diatas, teknik accidental Sampling ini jumlah sampelnya tidak ditetapkan terlebih dahulu, akan tetapi jumlah sampel akan diketahui setelah melakukan penelitian pada tempat dan waktu yang telah ditentukan oleh peneliti.

Uji coba instrumen dilakukan selama 2 minggu dengan 30 responden. Selanjutnya penelitian dilakukan selama 2 minggu berikutnya, terkumpul sebanyak 32 responden.

Teknik pengumpulan data yang digunakan dalam penelitian ini adalah kuesioner (angket). Kuesioner adalah sejumlah pertanyaan tertulis yang digunakan untuk memperoleh informasi dari responden dalam arti laporan tentang pribadinya, atau hal-hal yang ia ketahui.(4) Dalam hal ini peneliti menggunakan angket secara langsung dengan cara tertutup, dimana alternatif jawaban disediakan oleh peneliti. Tujuan dari kuesioner ini adalah untuk mengumpulkan data tentang pengaruh pelayanan terhadap kepuasan nasabah di Bank Muamalat Cabang Pembantu Sampit.

Sebelum digunakan sebagai alat pengumpul data, terlebih dahulu dilakukan uji coba terhadap instrumen yang ada. Dalam uji instrumen terdapat dua uji yang dilakukan yakni uji validitas dan uji reliabilitas.

Uji validitas merupakan suatu uji instrumen yang berkaitan dengan kemampuan instrumen itu untuk mengukur atau mengungkap karakteristik dari variabel yang dimaksudkan untuk diukur.(1)
Sebuah instrumen dikatakan valid apabila dapat mengungkapkan data dari variabel yang diteliti secara tepat. Tinggi rendahnya validitas instrumen menunjukkan sejauh mana data yang terkumpul tidak menyimpang dari gambaran tentang variabel yang dimaksud. Pengujian validitas menggunakan Korelasi Pearson Product Momen dengan $\alpha=$ $5 \%$ dan dilakukan dengan bantuan program SPSS (Statistical Product and Service Soulation) Versi 15.0 for windows.

Uji Reliabilitas adalah uji untuk mengukur kereliabilitasan suatu instrumen. Reliabel bisa diartikan sebagai keterpercayaan, keterandalan atau konsistensi. Suatu instrumen dikatakan reliabel atau handal jika jawaban seseorang terhadap pertanyaan adalah konsisten atau stabil dari waktu ke waktu.(5) Uji ini menggunakan bantuan program SPSS (Statistical Product and Service Soulation) Versi 15.0 for windows dengan kriteria instrument penelitian dikatakan reliabel apabila nilai alpha cronchbach 0,6.

Setelah terpenuhi syarat validitas dan reliabilitas, dilakukan pengumpulan data penelitian. Kemudian data penelitian yang diperoleh dianalisis menggunakan teknik statistik dengan bantuan komputer program Statistical Product and Service Soulation (SPSS) Versi 15 for windows dengan uji asumsi klasik (meliputi uji normalitas, uji linearitas dan uji autokorelasi), uji hipotesis, uji regresi linear sederhana, dan uji koefesien determinasi.

\section{Hasil dan Pembahasan}

Penelitian ini dilaksanakan di Bank Muamalat Cabang Pembantu Sampit. Bank Muamalat Cabang Pembantu Sampit merupakan salah satu Bank yang menjalankan sistem perbankan syariah di Indonesia khususnya di kota Sampit dengan melayani penghimpunan dana dan penyaluran dana serta jasa-jasa keuangan lainnya. Bank Muamalat Cabang Pembantu Sampit berada ditengah Kota yang cukup strategis sehingga memberikan keuntungan bagi pihak Bank untuk menarik minat masyarakat agar menjadi nasabah di Bank tersebut. Bank Muamalat Cabang Pembantu Sampit beralamat di Jl. AIS Nasution No.08 Sampit, Kecamatan Mentawa Baru Ketapang, 
Kabupaten Kotawaringin Timur, Sampit Kalimantan Tengah.

Bank Muamalat Cabang Pembantu Sampit mempunyai dua bidang yang melakukan kegiatan perbankan yaitu:

\section{a. Bidang Marketing}

Merupakan kegiatan menghimpun dana atau bisa didefinisikan sebagai suatu kegiatan membeli dana dari masyarakat. Melakukan kegiatan untuk mencari nasabah, mempromosikan dan memasarkan produk perbankan.

\section{b. Bidang Operasional}

Merupakan kegiatan yang memberikan layanan yang prima serta service yang excellence agar nasabah memahami produk yang ditawarkan serta menguntungkan bagi perusahaan dan nasabah tersebut.

Sejalan dengan visi dan misi serta maksud dan tujuan dari pendirian Bank Muamalat Cabang Pembantu Sampit yang telah ditetapkan oleh para pendiri selaku pemegang saham, maka Bank Muamalat Cabang Pembantu Sampit berusaha mewujudkannya melalui dengan terus menambah tenga kerja marketing serta meningkatkan mutu dan layanan untuk tujuan mencapai target yang lebih luas lagi.

Adapun visi dan misi serta maksud dan tujuan dari Bank Muamalat Cabang Pembantu Sampit sebagai berikut:

a. Visi

1) Menjadi Bank Syariah utama dominan dipasar emosional.

2) Menjadi Bank yang dikagumi pasar rasional.

b. Misi

Menjadi role model lembaga keuangan dunia dengan penekanan kepada semangat kewirausahaan, manajemen yang unggul dan orientasi investasi yang inovatif untuk memaksimumkan nilai kepada stake holder.

c. Maksud dan Tujuan

Adapun maksud dan tujuan berdirinya Bank Muamalat Cabang Pembantu Sampit adalah untuk memenuhi target perluasan jaringan layanan dan pengembangan jaringan bisnis organisasi serta mencapai target organisasi. Adapun maksud dan tujuan ini tidak akan terlaksana jika tidak didukung oleh bagian-bagian yang terlibat didalam organisasi tersebut. Berikut ini adalah struktur organisasi Bank Muamalat cabang pembantu Sampit yang terdapat pada gambar 1.

\section{Gambar 1 : Struktur Organisasi Bank Muamalat Cabang Pembantu Sampit}

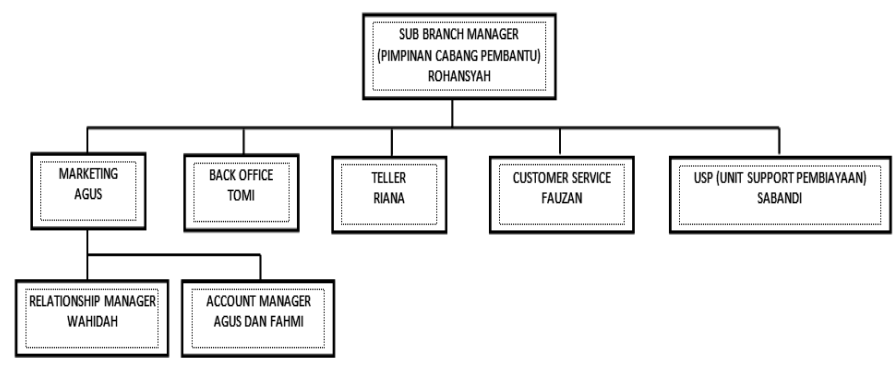

Keterangan:

a. Sub Branch Manager : Rohansyah

b. Marketing / MPR : Agus

c. Relationship Manager : Wahidah

d. Account Manager : Agus dan Fahmi

e. Back Office : Tomi

f. Teller : Riana

g. Customer Service : Fauzan

h. USP (Unit Support Pembiayaan) Sabandi

Responden penelitian ini adalah nasabah Bank Muamalat Cabang Pembantu Sampit. Data responden dalam penelitian ini dapat dilihat berdasarkan jenis kelamin nasabah (terdapat pada Tabel 1), usia nasabah (terdapat pada Tabel 2), pekerjaan nasabah terdapat pada Tabel 3, dan lamanya menjadi nasabah di Bank Muamalat Cabang Pembantu Sampit (terdapat pada Tabel 4).

a. Jenis Kelamin Responden

Data responden Bank Muamalat Cabang Pembantu Sampit dilihat berdasarkan jenis kelamin, terlihat pada tabel 1.

Tabel 1: Deskripsi Responden Berdasarkan Jenis Kelamin

\begin{tabular}{|c|c|c|}
$\begin{array}{c}\text { Jenis } \\
\text { Kelamin }\end{array}$ & $\begin{array}{c}\text { Jumlah } \\
\text { Responden }\end{array}$ & Persentase (\%) \\
\hline Pria & 9 & $28 \%$ \\
\hline Wanita & 23 & $72 \%$ \\
\hline Total & $\mathbf{3 2}$ & $\mathbf{1 0 0 \%}$ \\
\hline Sumber: Data Sekunder & \\
\hline
\end{tabular}


b. Usia Responden

Data responden Bank Muamalat cabang pembantu Sampit berdasarkan usia nasabah, terlihat pada tabel 2.

Tabel 2: Deskripsi Responden Berdasarkan Usia

\begin{tabular}{|c|c|c|}
$\begin{array}{c}\text { Usia } \\
\text { Responden }\end{array}$ & $\begin{array}{c}\text { Jumlah } \\
\text { Responden }\end{array}$ & $\begin{array}{c}\text { Persentase } \\
(\%)\end{array}$ \\
\hline$<15$ Tahun & 0 & $0 \%$ \\
\hline $\mathbf{1 6 - 1 9}$ & 1 & $3 \%$ \\
\hline $\mathbf{2 0 - 2 9}$ & 25 & $78 \%$ \\
\hline $\mathbf{3 0 - 4 0}$ & 6 & $19 \%$ \\
\hline $\mathbf{4 1 - 5 0}$ & 0 & $0 \%$ \\
\hline$>\mathbf{5 0}$ & 0 & $0 \%$ \\
\hline Total & $\mathbf{3 2}$ & $\mathbf{1 0 0 \%}$ \\
\hline
\end{tabular}

Sumber: Data Sekunder

c. Pekerjaan Responden

Data responden Bank Muamalat cabang pembantu Sampit berdasarkan pekerjaan nasabah, dijelaskan pada tabel 3 .

Tabel 3: Deskripsi Responden Berdasarkan Pekerjaan

\begin{tabular}{|c|c|c|}
\hline Pekerjaan & $\begin{array}{c}\text { Jumlah } \\
\text { Responden }\end{array}$ & $\begin{array}{c}\text { Persentase } \\
(\%)\end{array}$ \\
\hline PNS/TNI & 4 & $12 \%$ \\
\hline Wiraswasta & 1 & $3 \%$ \\
\hline Swasta & 1 & $3 \%$ \\
\hline Pelajar/Mahasiswa & 12 & $38 \%$ \\
\hline Ibu Rumah Tangga & 5 & $15 \%$ \\
\hline Lainnya & 9 & $29 \%$ \\
\hline Total & $\mathbf{3 2}$ & $\mathbf{1 0 0 \%}$ \\
\hline
\end{tabular}

Sumber: Data Sekunder

d. Lamanya Responden Jadi Nasabah

Data responden Bank Muamalat cabang pembantu Sampit berdasarkan lamanya menjadi nasabah, pada tabel 4 .

Tabel 4: Deskripsi Responden Berdasarkan Lamanya Menjadi Nasabah

\begin{tabular}{|c|c|c|}
$\begin{array}{c}\text { Lama Menjadi } \\
\text { Nasabah }\end{array}$ & $\begin{array}{c}\text { Jumlah } \\
\text { Responden }\end{array}$ & $\begin{array}{c}\text { Persentase } \\
(\%)\end{array}$ \\
\hline <1 Tahun & 4 & $12 \%$ \\
\hline 1-2 Tahun & 8 & $25 \%$ \\
\hline 3 Tahun & 20 & $63 \%$ \\
\hline Total & $\mathbf{3 2}$ & $\mathbf{1 0 0 \%}$ \\
\hline
\end{tabular}

\section{Sumber: Data Sekunder}

\section{Deskripsi Data Hasil Penelitian}

Deskripsi data hasil penelitian merupakan gambaran dari hasil penelitian yang telah dilakukan. Data dalam penelitian ini terdiri dari dua macam, yaitu data mengenai pelayanan dan data mengenai kepuasan nasabah dari 32 nasabah Bank Muamalat Cabang Pembantu Sampit.

Berdasarkan skor yang didapat, maka diperoleh gambaran umum mengenai pelayanan dan kepuasan nasabah di Bank Muamalat Cabang Pembantu Sampit. Berdasarkan hasil analisis, diperoleh gambaran umum skor variabel-variabel penelitian yang dapat dilihat pada tabel 5 .

Tabel 5: Deskripsi Data Penelitian Pelayanan dan Kepuasan Nasabah

\begin{tabular}{|c|c|c|c|c|c|}
\hline \multirow[t]{3}{*}{ Variabel } & \multirow[t]{3}{*}{$\mathbf{N}$} & \multicolumn{4}{|c|}{ Data Hipotetik } \\
\hline & & \multirow[t]{2}{*}{ Mean } & \multicolumn{2}{|c|}{ Skor } & \multirow[t]{2}{*}{ SD } \\
\hline & & & Min & Max & \\
\hline Pelayanan & 32 & 47,5 & 19 & 76 & 9,5 \\
\hline $\begin{array}{c}\text { Kepuasan } \\
\text { nasabah }\end{array}$ & 32 & 30 & 12 & 48 & 6 \\
\hline \multirow[t]{3}{*}{ Variabel } & \multirow[t]{3}{*}{$\mathbf{N}$} & \multicolumn{3}{|c|}{ Data Empirik } & \\
\hline & & \multirow[t]{2}{*}{ Mean } & \multicolumn{2}{|c|}{ Skor } & SD \\
\hline & & & Min & Max & \\
\hline Pelayanan & 32 & 66,97 & 57 & 71 & 3,07 \\
\hline $\begin{array}{l}\text { Kepuasan } \\
\text { nasabah }\end{array}$ & 32 & 39,44 & 35 & 44 & 2,31 \\
\hline
\end{tabular}

Tabel 5 menjelaskan bahwa pada skala pelayanan dan kepuasan nasabah diperoleh data hipotetik dan data empirik. Data hipotetik merupakan data atau skor yang diharapkan dapat dicapai oleh sampel penelitian, sedangkan data empirik merupakan data atau skor yang didapat dilapangan.

Skor hipotetik untuk variabel pelayanan diperoleh skor minimum sebesar 19, skor maksimum sebesar 76, mean sebesar 47,5, dan standar deviasi sebesar 9,5. Skor hipotetik untuk variabel kepuasan nasabah diperoleh skor minimum sebesar 12, skor 
maksimum sebesar 48 , mean sebesar 30 , dan standar deviasi sebesar 6 .

Skor empirik untuk variabel pelayanan diperoleh skor minimum sebesar 57, skor maksimum sebesar 71, mean sebesar 66,97, dan standar deviasi sebesar 3,07. Skor empirik untuk variabel kepuasan nasabah diperoleh skor minimum sebesar 35, skor maksimum sebesar 44, mean sebesar 39,44, dan standar deviasi sebesar 2,31.

Berdasarkan skor-skor tersebut maka akan dibuat kategorisasi. Tujuan kategorisasi adalah untuk menempatkan individu ke dalam kelompok-kelompok yang terpisah secara berjenjang menurut suatu kontinum berdasarkan atribut yang diukur. Banyaknya jenjang kategorisasi diagnosis yang digunakan tidak melebihi lima jenjang tapi juga tidak kurang dari tiga jenjang. Peneliti menetapkan tiga kategorisasi sesuai dengan tingkat deferensiasi yang dikehendaki, yaitu tinggi, sedang, dan rendah. Penetapan kategorisasi didasarkan pada satuan standar mean dan standar deviasi pada data empirik yang dapat dilihat pada tabel 6 .

Tabel 6: Kategorisasi Skor Pelayanan

\begin{tabular}{|c|c|c|c|c|c|}
\hline No & Pedoman & Skor & Kategori & Frekuensi & Persentase \\
\hline 1 & $\begin{array}{l}X_{\geq}(\mu+\sigma) \\
X_{\geq}(66,79+3,07)\end{array}$ & $x \geq 70,04$ & $\mathrm{~T}$ & 1 & $3 \%$ \\
\hline \multirow{2}{*}{2} & $(\mu-\sigma) \leq X<(\mu+\sigma)$ & \multirow{2}{*}{$63,9 \leq X<70,04$} & \multirow{2}{*}{$S$} & \multirow{2}{*}{27} & \multirow{2}{*}{$84 \%$} \\
\hline & $(66,97-3,07) \leq X<(66,79+3,07)$ & & & & \\
\hline \multirow{2}{*}{3} & $X<(\mu-\sigma)$ & \multirow{2}{*}{$X<63,9$} & \multirow{2}{*}{$R$} & \multirow{2}{*}{4} & \multirow{2}{*}{$13 \%$} \\
\hline & $\mathrm{X}<(66,97-3,07)$ & & & & \\
\hline \multicolumn{4}{|c|}{ Total } & 32 & $100 \%$ \\
\hline
\end{tabular}

Keterangan:

$\mathrm{X}=$ Skor Subjek

$\mu=$ Rerata (Mean) Empirik

$\sigma=$ Deviasi Standar Empirik

Berdasarkan tabel 6 diketahui bahwa persepsi subjek penelitian pada variabel pelayanan yang tergolong kedalam kategori tinggi sebanyak 1 nasabah (3\%), kategori sedang sebanyak 27 nasabah (84\%), dan kategori rendah sebanyak 4 nasabah (13\%). Hal tersebut memperlihatkan bahwa secara umum kecenderungan pelayanan termasuk kedalam kategori sedang. Kategori skor kepuasan nasabah diketahui dari subjek penelitian pada variabel kepuasan nasabah yang tergolong kedalam kategori tinggi, dapat dilihat pada tabel 7 .

Tabel 7: Kategorisasi Skor Kepuasan Nasabah

\begin{tabular}{|c|c|c|c|c|c|}
\hline $\mathrm{N}_{0}$ & Pedoman & Skor & Kategori & Frekuensi & Persentase \\
\hline 1 & $\begin{array}{l}X \geq(\mu+\sigma) \\
X \geq(39,44+2,31)\end{array}$ & $X \geq 41,75$ & $\mathrm{~T}$ & 7 & $22 \%$ \\
\hline \multirow{2}{*}{2} & $(\mu-\sigma) \leq X<(\mu+\sigma)$ & \multirow{2}{*}{$37,13 \leq X<451,7$} & \multirow{2}{*}{ S } & \multirow{2}{*}{17} & \multirow{2}{*}{$53 \%$} \\
\hline & $(39,44-2,31) \leq X<(39,44+2,31)$ & & & & \\
\hline \multirow{2}{*}{3} & $X<(\mu-\sigma)$ & \multirow{2}{*}{$X<37,13$} & \multirow{2}{*}{$R$} & \multirow{2}{*}{8} & \multirow{2}{*}{$25 \%$} \\
\hline & $\mathrm{X}<(39,44-2,31)$ & & & & \\
\hline \multicolumn{4}{|c|}{ Total } & 32 & $100 \%$ \\
\hline
\end{tabular}

Keterangan:

$\mathrm{X}=$ Skor Subjek

$\mu=$ Rerata (Mean) Empirik

$\sigma=$ Deviasi Standar Empirik

Berdasarkan tabel 7 diketahui bahwa subjek penelitian pada variabel kepuasan nasabah yang tergolong kedalam kategori tinggi sebanyak 7 nasabah (22\%), kategori sedang sebanyak 17 nasabah (53\%), dan kategori rendah sebanyak 8 nasabah $(25 \%)$. Hal tersebut memperlihatkan bahwa secara umum kecenderungan kepuasan nasabah termasuk kedalam kategori sedang.

Berdasarkan hasil kategorisasi menunjukkan bahwa secara umum pelayanan dalam penelitian ini tergolong sedang yaitu sebesar $84 \%$ dan kepuasan nasabah juga tergolong sedang sebesar 53\%. Berdasarkan teori hasil tersebut dapat disimpulkan bahwa semakin tinggi pelayanan maka akan semakin tinggi pula kepuasan nasabah. Hal tersebut dapat penulis gambarkan dalam bentuk grafik pada gambar 2 .

Gambar 2: Grafik Data Pelayanan dan Kepuasan Nasabah

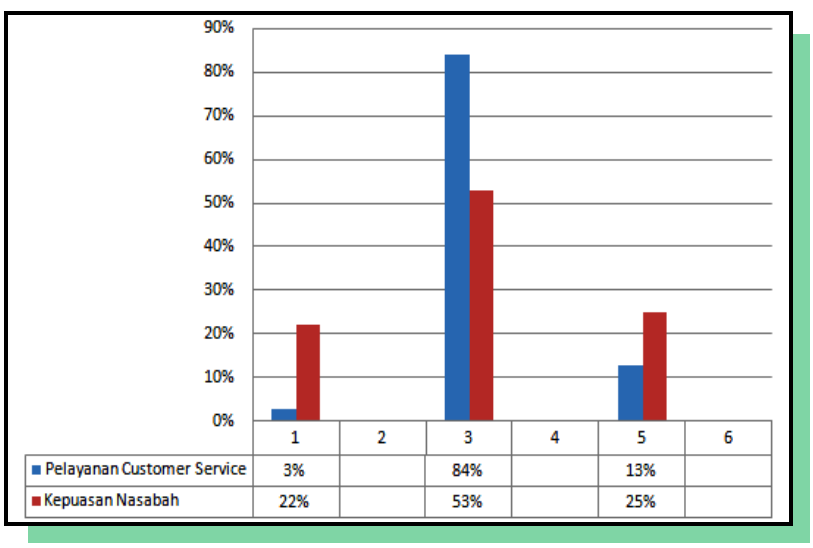


Dari data yang terkumpul dan setelah analisis menggunakan teknik statistik dengan bantuan program Statistical Product and Service Soulation (SPSS) Versi 15.0 for windows diperoleh hasil uji asumsi klasik (meliputi uji normalitas, uji linearitas dan uji autokorelasi), uji hipotesis, uji regresi linear sederhana, dan uji koefesien determinasi.

Dalam penelitian ini pengujian normalitas menggunakan pendekatan kolmogorov smirnov $(K-S)$ berdasarkan taraf signifikansi alpha 0.05. Hasil pengujian normalitas diperoleh taraf signifikansi pelayanan sebesar 0,083 dan nilai signifikansi kepuasan nasabah sebesar 0,721. Hal ini dapat disimpulkan bahwa data berdistribusi normal karena nilai signifikansi keduanya lebih besar dari 0,05 $(\mathrm{Sig}>0,05)$.

Pengujian linearitas data menggunakan pendekatan Test For Linearity pada taraf signifikansi 0,05 . Hasil pengujian linearitas didapat nilai signifikansi pada Linearity sebesar 0,045. Maka dapat disimpulkan bahwa antara variabel kepuasan nasabah dan pelayanan terdapat hubungan yang linear.

Uji autokorelai data menggunakan pendekatan Durbin Waston. Hasil didapat nilai Durbin-Waston sebesar 0.933. Karena angka D - W terdapat diantara - 2 sampai +2 maka dapat disimpulkan bahwa tidak ada autokorelasi (terbebas dari autokorelasi) pada model regresi.

Berdasarkan hasil analisis regresi linear sederhana diperoleh hasil $t_{\text {hitung }}$ sebesar 2,240. Karena $t_{\text {hitung }}>t_{\text {tabel }}(2,240>2,042)$ maka Ho ditolak. Hal ini menunjukkan bahwa hipotesis diterima, yaitu ada pengaruh pelayanan terhadap kepuasan nasabah di Bank Muamalat Cabang Pembantu Sampit.

Adapun model persamaan regresi linear sederhana yang diperoleh adalah $\mathrm{Y}^{\prime}=20,365$ $+0,285 X$. Nilai konstanta (a) adalah 20,365, ini dapat diartikan jika pelayanan (X) nilainya adalah 0, maka kepuasan nasabah (Y) nilainya 20,365. Nilai koefesien regresi (b) variabel pelayanan $(\mathrm{X})$ bernilai positif yaitu 0,285 ini dapat diartikan bahwa setiap peningkatan pelayanan $(\mathrm{X})$ sebesar 1 satuan, maka tingkat kepuasan nasabah (Y) juga akan meningkat sebesar 0,285.

Hasil uji koefesien determinasi diambil dari nilai $R$ Square. diperoleh angka $R$ Square sebesar 0,143 atau 14,3\%, ini menunjukkan bahwa presentase kontribus pengaruh variabel independen (pelayanan) terhadap variabel dependen (kepuasan nasabah) sebesar 14,3\%. Atau variasi variabel independen yang digunakan mampu menjelaskan sebesar $14,3 \%$ variasi variabel dependen. Sedangkan sisanya $85,7 \%$ dipengaruhi atau dijelaskan oleh variabel lain yang tidak diteliti dalam model penelitian ini.

Dengan demikian, berdasarkan hasil perhitungan tersebut diatas maka hipotesis yang diajukan dalam penelitian ini dapat diterima. Artinya ada pengaruh pelayanan terhadap kepuasan nasabah di Bank Muamalat Cabang Pembantu Sampit, dengan kontribusi pelayanan terhadap kepuasan nasabah sebesar $14,3 \%$.

Hasil penelitian ini sejalan dengan yang dilakukan oleh Khoiron yang menemukan adanya pengaruh kualitas pelayanan terhadap kepuasan nasabah pada Bank Syariah Mandiri Cabang Malang.(1) Hal ini didukung oleh pernyataan Tjiptono, bahwa kualitas jasa mempunyai pengaruh yang signifikan terhadap kepuasan pelanggan.(10)

\section{Kesimpulan}

Berdasarkan hasil kategorisasi skor pelayanan dan kepuasan nasabah, secara umum menunjukkan bahwa dalam penelitian ini pelayanan di Bank Muamalat Cabang Pembantu Sampit termasuk dalam kategori sedang dengan persentase sebesar $84 \%$. Sedangkan untuk kategori tinggi diperoleh persentase sebesar 3\% dan kategori rendah sebesar 13\%. Kepuasan nasabah di Bank Muamalat Cabang Pembantu Sampit, dalam penelitian ini termasuk dalam kategori sedang dengan persentase 53\%. Sedangkan untuk kategori tinggi diperoleh persentase sebesar $22 \%$ dan kategori rendah sebesar 25\%. Berdasarkan hasil analisis regresi linear sederhana dengan bantuan program SPSS diperoleh nilai thitung sebesar 2,240. $\mathrm{t}_{\text {hitung }}>$ $t_{\text {tabel }}(2,240>2,042)$ menunjukkan bahwa hipotesis yang diajukan dalam penelitian ini diterima. 


\section{Daftar Pustaka}

1. Ahmad Khoiron. Pengaruh Kualitas Pelayanan Terhadap Kepuasan Nasabah Pada Bank Syariah Mandiri Cabang Malang. Universitas Islam Negeri Maulana Malik Ibrahim: 2010.

2. Amalia CH. Hubungan Antara Kepuasan Konsumen dan Kualitas Pelayanan Dengan Loyalitas Konsumen Pada Ritel Modern [Online]. Universitas Sebelas Maret: 2010. https://eprints.uns.ac.id/6886/ [4 Apr. 2018].

3. Arif, M. N. Dasar-Dasar Pemasaran Bank Syari'ah. Bandung: Alfabeta, 2010.

4. Arikunto S. Prosedur Penelitian: Suatu Pendekatan Praktik. Jakarta: Rineka Cipta, [date unknown].

5. Ascarintya P, Yoestini Y. Analisis Pengaruh Kualitas Pelayanan Terhadap Kepuasan Nasabah (Studi Pada Nasabah Debitur PT. BPR Satria Pertiwi Semarang) [Online]. Universitas Diponegoro: 2011. http://eprints.undip.ac.id/26692/ [4 Apr. 2018].

6. Effendi, M. G. Transformasi Manajemen Pemasaran. Jakarta: Sagung Seto, 2010.

7. Hamdi, A. S. Metode Penelitian Kuantitatif Aplikasi Dalam Pendidikan. Yogyakarta: Budi Utama, 2014.
8. Kasmir. Bank dan Lembaga Keuangan Lainnya. Jakarta: Raja Grafindo Persada, 2010 .

9. Kasmir. Manajemen Perbankan. Jakarta: Raja Grafindo Persada, 2010.

10. Lovenia, C. O. Analisis Pengaruh Kualitas Pelayanan Terhadap Kepuasan Nasabah. Semarang: Universitas Diponegoro, 2012.

11. Nova Rina Nur Latifah. Pengaruh Kualitas Pelayanan Customer Service Terhadap Loyalitas Pelanggan Pada Plasa Telkom Kandatel Yogyakarta [Online]. UIN Sunan Kalijaga Yogyakarta: 2011. http://digilib.uinsuka.ac.id/5302/ [4 Apr. 2018].

12. Stokes, J. How To Do Media And Cultural Studies: Panduan Untuk Melaksanakan Penelitian Dalam Kajian Media dan Budaya. Yogyakarta: Bentang Pustaka, 2007.

13. Suharto, A. M. Customer Service Dalam Bisnis Jasa Transportasi. Jakarta: 2009.

14. Sukardi. Metodologi Penelitian Pendidikan. Jakarta: Bumi Aksara, 2010.

15. Wardiah, M. L. Dasar-Dasar Perbankan. Bandung: Pustaka Setia, 2013.A 